\title{
Assessing the invasive potential of commercial Eucalyptus species in Brazil: Germination and early establishment
}

\author{
Paulo Henrique Muller da Silva ${ }^{\mathrm{a}, \mathrm{b}, *}$, Jean-Pierre Bouillet ${ }^{\mathrm{c}, \mathrm{d}}$, Rinaldo Cesar de Paula ${ }^{\mathrm{b}}$ \\ a IPEF - Instituto de Pesquisas e Estudos Florestais, Avenida Pádua Dias 11, Caixa Postal 530, CEP 13400-970 Piracicaba, SP, Brazil \\ ${ }^{\mathrm{b}}$ UNESP - Universidade Estadual "Júlio de Mesquita Filho"/FCAV - Faculdade de Ciências Agrárias e Veterinárias, Via de Acesso Prof. Donato Castellane S/N, \\ 14884-900 Jaboticabal, SP, Brazil \\ ${ }^{\mathrm{C}}$ CIRAD, UMR EcoESols, Montpellier, France \\ ${ }^{\mathrm{d}}$ USP-ESALQ Departamento de Ciências Florestais, Av. Pádua Dias, 11 Caixa Postal 9, CEP13418-900 Piracicaba, SP, Brazil
}

\section{A R T I C L E I N F O}

\section{Article history:}

Received 14 December 2015

Received in revised form 2 May 2016

Accepted 3 May 2016

Available online 11 May 2016

\section{Keywords:}

Alien species

Invasiveness

Environmental conditions

Seed germination

Substrate water potential

Air moisture

\begin{abstract}
A B S T R A C T
The invasive potential of a species is related to the interaction between genetic and environmental characteristics, as climatic conditions and native vegetation, reflecting the species adaptation to local conditions. An ecologically-adapted alien species can alter diversity and structure of forest ecosystems. This study assessed the invasiveness potential of eight commercially important Eucalyptus species in the germination and early establishment phases in southeastern Brazil. The first experiment evaluated seed germination under controlled temperature and air humidity conditions testing six substrate water potentials. The second experiment was conducted in pots to evaluate seed germination and seedling mortality under rainfed and irrigated regimes. Nine field trials were set up in the third experiment in six locations. In each trial, 80 plots of $1 \mathrm{~m}^{2}$ were installed with half the plots undisturbed and half where preexisting plants and litter were removed. In the first experiment, Eucalyptus taxa differed significantly in seed germination for substrate water potential $\geqslant-0.6 \mathrm{MPa}$. No germination was found for any taxa at $-0.8 \mathrm{MPa}$ substrate water potential. In the second experiment, differences in germination between species and water treatments were observed 21 days after sowing. No mortality was found in the irrigated treatments. No seedling mortality was observed in the rainfed treatments when the relative air humidity was higher than $85 \%$, even during a dry period of 45 days. By contrast, seedling mortality was observed for all taxa in all the rainfed treatments when relative air humidity fell under $80 \%$. In the third experiment, germination and seedling establishment of Eucalyptus species was always very low. The nonEucalyptus species showed differences in germination between trials and soil exposures. Our results showed that soil and air moisture were major drivers of eucalypt germination and initial establishment in controlled conditions. However, under field conditions additional factors such as competition of nonEucalyptus species and seedlings predation drastically limited eucalypt establishment suggesting low ecological adaptation of Eucalyptus sp. as an invasive species.
\end{abstract}

(c) 2016 Elsevier B.V. All rights reserved.

\section{Introduction}

Eucalypts are used in commercial forest plantations due to their high growth rates, adaptability to various ecological conditions (e.g. elevation, climates, soils) and multiple uses (e.g. raw material, energy wood, timber, pulp and paper). In recent decades, significant increases in productivity have been obtained through Eucalyptus taxa selection and breeding, plant protection and management practices (Gonçalves et al., 2013). However, there are concerns

\footnotetext{
* Corresponding author at: IPEF - Instituto de Pesquisas e Estudos Florestais, Avenida Pádua Dias 11, Caixa Postal 530, CEP 13400-970 Piracicaba, SP, Brazil.

E-mail address: paulohenrique@ipef.br (P.H.M.d. Silva).
}

about the environmental impacts of commercial eucalypt stands (Silva et al., 2014). One major concern is eucalypt invasion which may happen in any ecosystem when favourable conditions occur (Larcombe et al., 2013; Tererai et al., 2013). Few studies have been carried out to assess the invasive potential of seedlings of Eucalyptus species from planted stands into native forests either in its native range in Australia (Larcombe et al., 2013) or in exotic environments such as the United States (Booth, 2012; Gordon et al., 2012; Callaham et al., 2013; Lorentz and Minogue, 2015) or Brazil (Silva et al., 2011).

The invasiveness of a species is a consequence of the interaction between genetic and environmental characteristics reflecting the adaptation of that species to local conditions (Godfree et al., 
2004; Erfmeier and Bruelheide, 2010). Temperature, air and soil humidity are usually key factors for seed germination and seedlings establishment (Kozlowski, 2002; Mc Carragher et al., 2011; StantonGeddes et al., 2012) as observed for soil water potential for Eucalyptus species (Arnold et al., 2014). However, these factors may vary between species. An ecologically-adapted alien species may cause habitat loss of endangered species and alter genetic diversity and forest ecosystems structure (Gurevitch and Padilla, 2004; Williams and Wardle, 2007). Species with a broader tolerance of environmental conditions could present higher potential risk of invasion than less tolerant species (Higgins and Richardson, 2014).

Nine Eucalyptus species are used in more than $90 \%$ of the current plantations (Harwood, 2011). Eucalypts have been planted extensively beyond their natural range in more than 90 countries and have become invasive in a few places (Mattei and Longhi, 2001; Forsyth et al., 2004; Ruthrof, 2004). According to Gordon et al. (2012), some widely used Eucalyptus species of the Symphyomyrtus subgenus (Eucalyptus globulus Labill., Eucalyptus camaldulensis Dehnh., Eucalyptus grandis W. Hill ex Maiden, Eucalyptus saligna Sm. and Eucalyptus urophylla S.T. Blake) present potential risk of becoming invasive in the USA. It is therefore important to get insights into the conditions that affect germination and early establishment of the seedlings of these species to ensure appropriate management of commercial stands. This issue can be addressed in field experiments established across appropriate ecological ranges (Flory et al., 2012) in regions where Eucalyptus plantations are already established as well as in areas where commercial companies intend to deploy new plantations (Richardson and Rejmánek, 2011).

This study was conducted in six regions in Brazil under different climatic/ecological conditions with five pure species (E. camaldulensis, Eucalyptus pellita F. Muell, E. grandis, E. urophylla, E. saligna) and three hybrids (E. urophylla $\times E$. grandis, E. globulus $\times E$. spp., Eucalyptus dunnii Maiden $\times$ E. spp.) of eucalypts. This work extended that of Silva et al. (2011) dealing with the invasiveness potential of seedlings from $E$. grandis and hybrid of $E$. urophylla $\times E$. grandis clones in three regions in Brazil.

A key determinant of invasion potential is the ability for species to reproduce effectively in a novel environment (Perkins et al., 2011; Booth, 2015). Understanding the effect of environmental factors such as substrate moisture and air humidly on germination, and ecological factors such as competition with native species, will therefore provide clues to the invasive potential of introduced species. Two questions were therefore addressed in the present study: how do substrate moisture and air humidity affect seed germination and seedling survival of Eucalyptus species? How do seed germination and early establishment under controlled and uncontrolled conditions differ among Eucalyptus species?

\section{Materials and methods}

Three experiments were set up in various locations and ecological conditions. We selected eucalypts that are among the most planted species worldwide (Harwood, 2011), whose seeds are produced in Brazil. The seedlots were bulks of open pollinated seeds collected from at least 12 trees in a seed orchard for each species. The same seedlots were used in the three experiments (Table 1). For a given species, germination rate of $100 \%$, considered as reference seedling germination in experiments one and two, was estimated by counting the number of seedlings 14 days after sowing one gram of seeds + chaff in controlled conditions, as described in the experiment one with substrate water potential of $0 \mathrm{MPa}$.

The first experiment aimed at evaluating the germination of Eucalyptus species seeds under controlled conditions of temperature $\left(25^{\circ} \mathrm{C}\right)$ and air humidity with substrate water potentials $\left(\Psi_{s}\right)$ of $0.0,-0.2,-0.4,-0.6,-0.8$, and $-1.0 \mathrm{MPa}$. The water potential control was achieved by adding a polyethylene glycol 6000 solution to a paper substrate (Villela et al., 1991). For each taxon, five replicates of $0.1 \mathrm{~g}$ seed were sown for each value of substrate water potential. Seedlings were counted at 14 days after sowing (DAS). The experiment was conducted in the laboratory of Sementes e Melhoramento Florestal (Seeds and Forest Improvement) - UNESP Jaboticabal (latitude: $21^{\circ} 08 \mathrm{~S}$; longitude: $48^{\circ} 11 \mathrm{~W}$; elevation: $583 \mathrm{~m}$ a.s.l.).

The second experiment was conducted at the IPEF nursery in Piracicaba, São Paulo State, Brazil, (Koppen classification: Cwa, latitude: $22^{\circ} 25^{\prime} \mathrm{S}$; longitude: $47^{\circ} 22^{\prime} \mathrm{W}$; elevation: $554 \mathrm{~m}$ a.s.l.; mean annual temperature: $21.6^{\circ} \mathrm{C}$; mean annual precipitations: $1260 \mathrm{~mm})$. A complete randomized design was set up with 16 treatments ( 8 species $\times 2$ water regimes) and four blocks. This experiment aimed at evaluating the germination of Eucalyptus seeds and the initial establishment of seedlings under rainfed condition or irrigated with $5 \mathrm{~mm}$ of tap water, three times a week. For each taxon, $1 \mathrm{~g}$ of seed was sown in pots of $50 \mathrm{dm}^{3}$ filled with river sand. The number of seedlings was counted at $6,7,10,13,15,17$, $21,29,38,55,107$ and 140 DAS. Rainfall, temperature and relative air humidity were measured daily during the experiment period.

The third experiment aimed at evaluating under field conditions the establishment of seedlings of the different eucalypt species/hybrids. Nine trials were set up in six locations (Table 2), during spring and summer when high precipitations occur and the Eucalyptus species studied have viable seeds in southeast Brazil. (I. Vieira, IPEF Seeds Coordinator, personal communication). In each trial, 80 plots of $1 \mathrm{~m}^{2}$ were established with 40 plots where the soil and vegetation was undisturbed (hereafter referred to as "soil unchanged" - SU) and 40 plots where plants and soil litter were removed (hereafter referred to as "bare soil" - BS). In each plot, $1 \mathrm{~g}$ of seeds was sowed, representing a potential of $>200$ seeds $\mathrm{m}^{-2}$. A split-plot design with five blocks was set up with taxon as whole plot factor and soil exposure (SU or BS) as subplot factor. The trial was replicated one year after the first sowing in three locations in order to check possible variations between years in seedling germination and seedling establishment. The plots were assessed at approximately 10-day intervals for at least 40 DAS. The number of eucalypt seedlings that had germinated

Table 1

Studied eucalypts taxa and seed lot provenances.

\begin{tabular}{llll}
\hline Code & Species & Section & Provenance \\
\hline 1 & E. camaldulensis & Exsertaria & Selvíria, MS (SPA-F1) \\
2 & E. dunnii $\times$ E. spp. ${ }^{\text {a }}$ & Maidenaria & Itatinga, SP T6 H27 (SPA-F2) \\
3 & E. globulus $\times$ E. spp. ${ }^{\text {a }}$ & Maidenaria & Camanducaia, MG (SPA-F1) \\
4 & E. grandis & Latoangulata & Lençóis Pta., SP T16601 (SPA-F2) \\
5 & E. saligna & Latoangulata & Itatinga, SP T20 (SPA-F1) \\
6 & E. pellita & Latoangulata & Anhembi, SP T19C113 (SPA-F1) \\
7 & E. urophylla $\times$ E. grandis $($ E. urograndis $)$ & Latoangulata & Itatinga, SP T23A079 (SO-F2) \\
8 & E. urophylla & Latoangulata & Piracicaba, SP 02AV01 (SPA-F2) \\
\hline
\end{tabular}

a Pure species are not found in the areas of seed production. MS: Mato Grosso do Sul state; SP: São Paulo state; MG: Minas Gerais state; SPA: Seeds Production Area; and SO = Seed Orchard. 
Table 2

Main site characteristics.

\begin{tabular}{|c|c|c|c|c|c|c|c|c|c|c|}
\hline & Site code & Location & $\begin{array}{l}\text { Date of } \\
\text { sowing }\end{array}$ & $\begin{array}{l}\text { Climatic } \\
\text { classification }^{\text {a }}\end{array}$ & $\begin{array}{l}\text { Annual rainfall } \\
\left(\mathrm{mm} \mathrm{yr}^{-1}\right)\end{array}$ & AAT $\left({ }^{\circ} \mathrm{C}\right)$ & Latitude & Longitude & $\begin{array}{l}\text { Elevation } \\
(\mathrm{m})\end{array}$ & Natural vegetation \\
\hline 1 & $\begin{array}{l}\text { ITA-1 } \\
\text { ITA-2 }\end{array}$ & Itatinga, SP & $\begin{array}{l}20 / 10 / 2013 \\
13 / 01 / 2015\end{array}$ & Cwa & 1372 & 19.7 & $23^{\circ} 30^{\prime} \mathrm{S}$ & $48^{\circ} 22^{\prime} \mathrm{W}$ & 840 & Savannah \\
\hline 2 & JAC & Jacareí, SP & $06 / 01 / 2014$ & Cwa & 1233 & 21.3 & $23^{\circ} 10^{\prime} \mathrm{S}$ & $45^{\circ} 34^{\prime} \mathrm{W}$ & 680 & Semideciduous forest \\
\hline 3 & $\mathrm{CBO}$ & Capão Bonito, SP & $01 / 02 / 2014$ & Cwa & 1121 & 21.2 & $24^{\circ} 00^{\prime} \mathrm{S}$ & $48^{\circ} 12^{\prime} \mathrm{W}$ & 660 & Seasonal-Atlantic forest \\
\hline 4 & TLG & Três lagoas, MS & $06 / 01 / 2014$ & Aw & 1180 & 26.0 & $20^{\circ} 52^{\prime} \mathrm{S}$ & $51^{\circ} 53^{\prime} \mathrm{W}$ & 399 & Savannah/Pasture \\
\hline 5 & $\begin{array}{l}\text { ARA-1 } \\
\text { ARA-2 }\end{array}$ & Araraquara, SP & $\begin{array}{l}12 / 11 / 2013 \\
05 / 12 / 2014\end{array}$ & Aw & 1430 & 21.7 & $21^{\circ} 28^{\prime} \mathrm{S}$ & $48^{\circ} 50^{\prime} \mathrm{W}$ & 660 & Savannah \\
\hline 6 & $\begin{array}{l}\text { ANG-1 } \\
\text { ANG-2 }\end{array}$ & Angatuba, SP & $\begin{array}{l}22 / 11 / 2013 \\
01 / 12 / 2014\end{array}$ & Cwa & 1282 & 20.9 & $23^{\circ} 17^{\prime} \mathrm{S}$ & $48^{\circ} 15^{\prime} \mathrm{W}$ & 620 & Savannah/Semideciduous forest \\
\hline
\end{tabular}

a Koppen climatic classification: Cwa- Temperate Dry Winter and Hot Summer; Aw- Tropical Savanna; AAT: Annual Average Temperature.

from the Eucalyptus seeds was counted at least four times per trial, as well as the number of seedlings of non-eucalypt species that had germinated from the soil seed bank in the same plots.

Experiment one was analyzed by PROC GLM procedure of SAS 6.11 (SAS Institute, Cary, NC, USA), considering species and water regime as fixed effects. A Tukey test was used to calculate the minimum significant difference among eucalypts taxa in each water regime. The significance level was 0.05 . The effect of water regime for a given species was analyzed using the Sigmoidal logistic function by Origin 6.0 software: $y=\frac{a}{1+e^{-k\left(x-x_{c}\right)}}$, were: $\mathrm{y}=$ germination rate; $\mathrm{a}=$ maximum germination; $\mathrm{k}=$ relative rate of reduction; $\mathrm{x}=$ substrate water potential; and $\mathrm{x}_{\mathrm{c}}=$ substrate water potential of $50 \%$ germination.

Experiment two was analyzed by PROC MIXED procedure of SAS 6.11 (SAS Institute, Cary, NC, USA) to fit an unstructured variance matrix, considering block and age as random effects and species as fixed effect. Homogeneity of variances was tested by the Levene's test and the normal distribution of residuals was tested by the Shapiro-Wilks test. The significance level was 0.05 .

Experiment three was not statistically analyzed due to very poor establishment of Eucalyptus seedlings in all the trials.

\section{Results}

The reference seedling germinated differed between eucalypts taxa. Fourteen days after sowing one gram of seeds and chaff, the number of seedlings was 992 for E. camaldulensis, 560 for E. dunnii $\times$ Eucalyptus ssp., 1510 for E. globulus $\times$ Eucalyptus ssp., 1880 for E. grandis, 507 for E. saligna, 255 for E. pellita, 865 for Eucalyptus urograndis, and 397 for E. urophylla.

\subsection{Seed germination $\times$ substrate moisture}

There were highly significant differences between species $(\mathrm{DF}=7 ; \mathrm{F}=9.13 ; \mathrm{p}<0.001)$ and water regime $(\mathrm{DF}=5 ; \mathrm{F}=364.19$; $\mathrm{p}<0.001)$. The interaction between these two factors was highly significant $(\mathrm{DF}=35 ; \mathrm{F}=5.14 ; \mathrm{p}<0.001)$. The substrate water potential corresponding to $50 \%$ of seeds germination varied from -0.16 up to $-0.53 \mathrm{MPa}$ (Table 3). Germination of E. globulus $\times$ Eucalyptus spp. seeds was the most sensitive to substrate moisture with percentage of only $40 \%$ of the reference seedling germination at $-0.2 \mathrm{MPa}$, when $E$. urophylla was the less sensitive to the substrate dryness with still $43 \%$ of the reference seedling germination at $-0.6 \mathrm{MPa}$ (Fig. 1).

\subsection{Seed germination and seedling establishment under two water regimes}

There were highly significant differences between species $(\mathrm{DF}=7 ; \mathrm{F}=20.14 ; \mathrm{p}<0.001)$ and water regime $(\mathrm{DF}=1$; $\mathrm{F}=164.21 ; \mathrm{p}<0.001)$. The interaction between these two factors
Table 3

Average ( \pm standard error) substrate water potential corresponding to $50 \%$ seed germination rate and relative rate of reduction germination - Experiment 1 .

\begin{tabular}{llrrr}
\hline Species & \multicolumn{2}{l}{$\begin{array}{l}\text { Water potential for } 50 \% \\
\text { germination }\left(X_{c}\right)\end{array}$} & \multicolumn{2}{l}{$\begin{array}{l}\text { Relative rate of } \\
\text { reduction }(k)\end{array}$} \\
\hline E. globulus $\times$ E. spp. & -0.16 & $\pm 0.009 \mathrm{MPa}$ & 13.25 & \pm 1.34 \\
E. dunnii $\times$ E. spp. & -0.23 & $\pm 0.052 \mathrm{MPa}$ & 7.78 & \pm 1.88 \\
E. urograndis & -0.29 & $\pm 0.046 \mathrm{MPa}$ & 6.81 & \pm 1.28 \\
E. saligna & -0.32 & $\pm 0.011 \mathrm{MPa}$ & 9.84 & \pm 0.78 \\
E. pellita & -0.33 & $\pm 0.098 \mathrm{MPa}$ & 6.07 & \pm 2.21 \\
E. grandis & -0.39 & $\pm 0.018 \mathrm{MPa}$ & 8.05 & \pm 0.91 \\
E. camaldulensis & -0.42 & $\pm 0.014 \mathrm{MPa}$ & 14.00 & \pm 3.02 \\
E. urophylla & -0.53 & $\pm 0.048 \mathrm{MPa}$ & 8.20 & \pm 2.62 \\
\hline
\end{tabular}

was also highly significant ( $\mathrm{DF}=7 ; \mathrm{F}=4.15 ; \mathrm{p}=0.0013$ ). E. camaldulensis showed the highest difference in number of seedlings between the two water regimes. For instance at 21 DAS, 531 seedlings were counted in the irrigated treatment and 150 in the rainfed treatment. By contrast, E. urophylla presented only a slight increase $(\approx+20 \%)$ in the number of seedlings in the irrigated treatment compared to the rainfed treatments (Table 4). No seedling mortality was observed after germination in the irrigated treatments during the trial period. In the rainfed treatments, seedling mortality was not observed in April and May, even after a 45-day dry period. However, air relative humidity was high during this event with an average value of $87 \%$. Seedling mortality was observed in all rainfed treatments when air relative humidity fell under $85 \%$, as observed in the last week of July and August for all Eucalyptus taxa (Fig. 2).

\subsection{Establishment of Eucalyptus and non-Eucalyptus seedlings in field conditions}

Eucalyptus taxa showed very low seed germination and seedlings establishment in all trials. Germination of non-Eucalyptus species was observed in six of nine trials. No germination of nonEucalyptus species was found in the driest conditions, for example in sites ITA-1, ARA-1 and ANGA-1 (Table 1 in appendix). When seed germination occurred many more seedlings were observed when plant and litter were removed before sowing (BS). In Capão Bonito (CBO) seed germination of non-Eucalyptus species was observed in both soil exposures. However, there were 30 times more seedlings of non-Eucalyptus species for BS than SU. The non-Eucalyptus species germinated well and presented no seedling mortality in the locations where the relative air humidity was higher than $85 \%$ during the study period (Fig. 1 in appendix - CBO site).

\section{Discussion}

Germination and initial establishment of Eucalyptus seeds depended on the substrate and air humidity. Large differences 


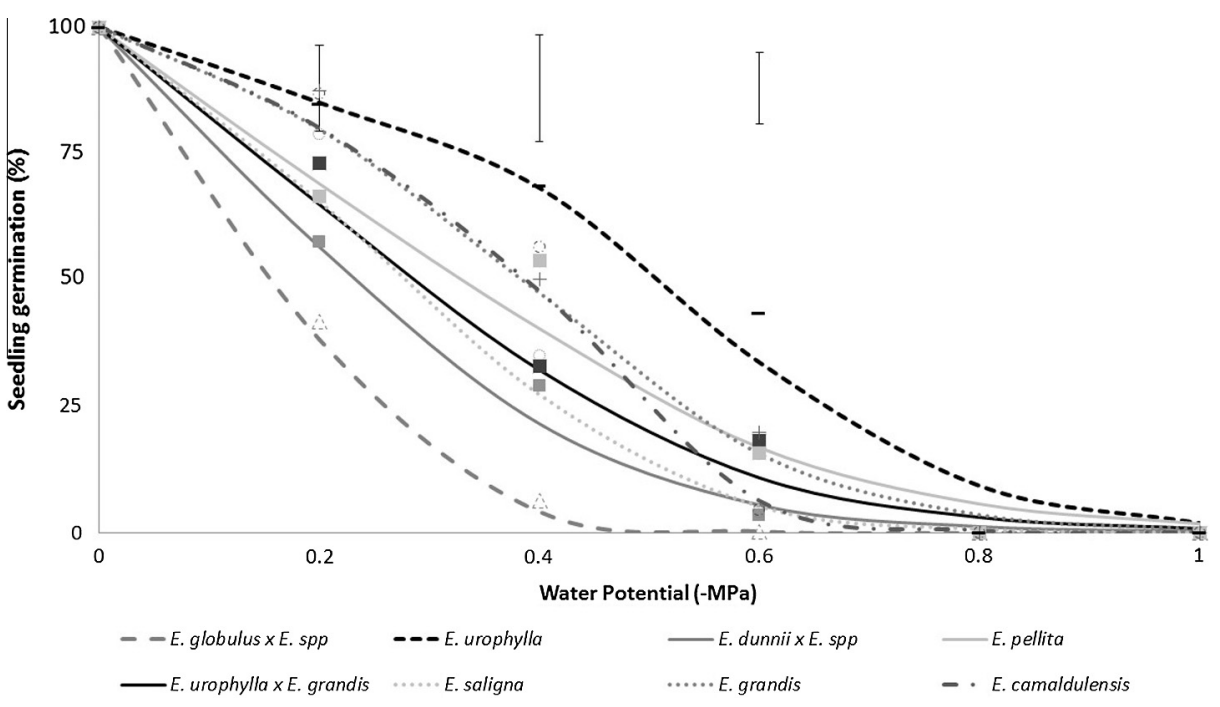

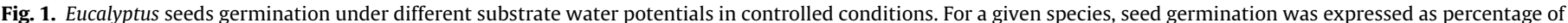

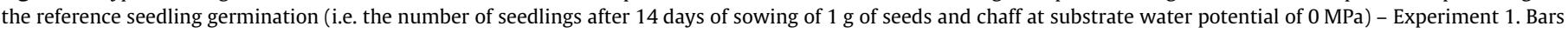

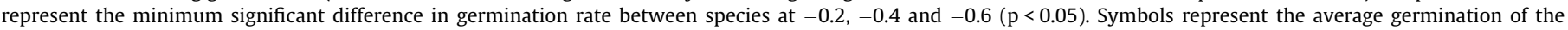
different species at $-0.2,-0.4,-0.6$, and $-0.8 \mathrm{MPa}$.

Table 4

Average number of seedlings at 21 days after sowing in the irrigated and rainfed treatments under nursery conditions (Experiment 2).

\begin{tabular}{|c|c|c|c|c|}
\hline \multirow[t]{2}{*}{ Species } & \multicolumn{2}{|c|}{ Number of seedlings } & & \multirow{2}{*}{$\begin{array}{l}\text { Ratio } \\
\text { I/R }\end{array}$} \\
\hline & Irrigated (I) & Rainfed (R) & & \\
\hline E. urophylla & 143 & 115 & * & 1.2 \\
\hline E. dunnii $\times$ E. spp. & 173 & 109 & $*$ & 1.6 \\
\hline E. pellita & 130 & 63 & ** & 2.1 \\
\hline E. saligna & 206 & 91 & $* *$ & 2.3 \\
\hline E. grandis & 377 & 135 & $* *$ & 2.8 \\
\hline E. urograndis & 363 & 104 & ** & 3.5 \\
\hline E. camaldulensis & 531 & 150 & ** & 3.5 \\
\hline E. globulus $\times$ E. spp. & 84 & 19 & $*$ & 4.5 \\
\hline
\end{tabular}

Water regimes were compared for a given species.

* Indicates that $0.05>\mathrm{p}>0.01$.

** Indicates that $\mathrm{p}<0.01$.

were observed in germination and initial establishment under controlled conditions between the Eucalyptus taxa. No germination of Eucalyptus species was observed when the substrate moisture was lower than $-0.8 \mathrm{MPa}$, which is half the value of the water potential required for the germination of Leucena leucocephala seeds (Cavalcante and Perez, 1995). Daws et al. (2008) observed germination of Ochroma pyramidale at $-1.8 \mathrm{MPa}$. These authors also suggested that some species with small seeds, such as Eucalyptus, could germinate only in moist microsites to avoid mortality due to drought.

Under controlled conditions E. globulus and E. camaldulensis showed the highest reduction in relative rates in experiment one (Table 3) and the highest percentages of reduction in germination between irrigated and rainfed conditions in experiment two (Table 4). In experiment one, the difference between the two species was the substrate moisture at the inflection point of the germination curve that was lower for $E$. camaldulensis ( $\approx-0.04 \mathrm{MPa}$ ) than for E. globulus ( $\approx-0.02 \mathrm{MPa}$ ). E. globulus is native from southern Australia (Victoria and Tasmania states) with dry summer and wet winter (Mediterranean climate). Consistently, E. globulus is naturalised in many parts and may be invasive in some areas of California (USA) likely due to its adaptation to the Mediterranean climatic conditions of this region (Ritter and Yost, 2009). E. camaldulensis is spread across Australia, along the rivers, in flood habitat, as found in riparian vegetation in Western Cape, South Africa where this species is invasive (Tererai et al., 2013). It might be then considered as an evolutionary result that both species could germinate well and be invasive only when climatic conditions are similar to those of their region of origin. In the other hand E. urophylla which is a tropical species largely deployed in tropical or subtropical regions showed low sensibility to water regimes in experiment one and two. However, as far as we are aware this species is not known be invasive.

Atmospheric humidity was likely another key factor regulating the germination and the establishment of Eucalyptus species. In controlled conditions without irrigation, no Eucalyptus seedlings survived when the relative air humidity was lower than $85 \%$ for a few days in experiment two. No seed germination or survival of Eucalyptus species and non-Eucalyptus seedlings was observed in field conditions too, when the relative air humidity was lower than $85 \%$ (experiment three). Leaf wetness that occurs with high relative humidity (>90\%) (Sentelhas et al., 2008) might improve the initial survival of the seedlings. However, in various locations of our study, no establishment of Eucalyptus seedlings was observed in field conditions even with high levels of air humidity. By contrast, the number of E. globulus wildings in plantation boundary increased in Australia on the sites that received regular high rainfall (Larcombe et al., 2013). Further studies are needed to gain insights into the conditions (e.g. top soil characteristics and biotic interactions) allowing some Eucalyptus species germination in their dry natural environment (Boland et al., 2006).

The germination was much higher on the bare soils than when the soils were left undisturbed, as already observed in field conditions for Eucalyptus amplifolia, E. camaldulensis and E. grandis in Florida, USA (Lorentz and Minogue, 2015) and for seedlings from clonal plantations of E. grandis and E. urophylla $\times$ E. grandis in Brazil (Silva et al., 2011). Bare soil and reliable water availability improved germination of both Eucalyptus species and non-Eucalyptus species. However, even with adequate soil exposure and air humidity, a very low germination of eucalypt seeds was observed in field conditions regardless of the Eucalyptus species. When some seeds are able to germinate, high mortality usually occurs during the initial phases of seedling development (Booth et al., 2015) due to factors such as competition of non-Eucalyptus species for light capture and soil water uptake (Booth, 2014). In our study, 

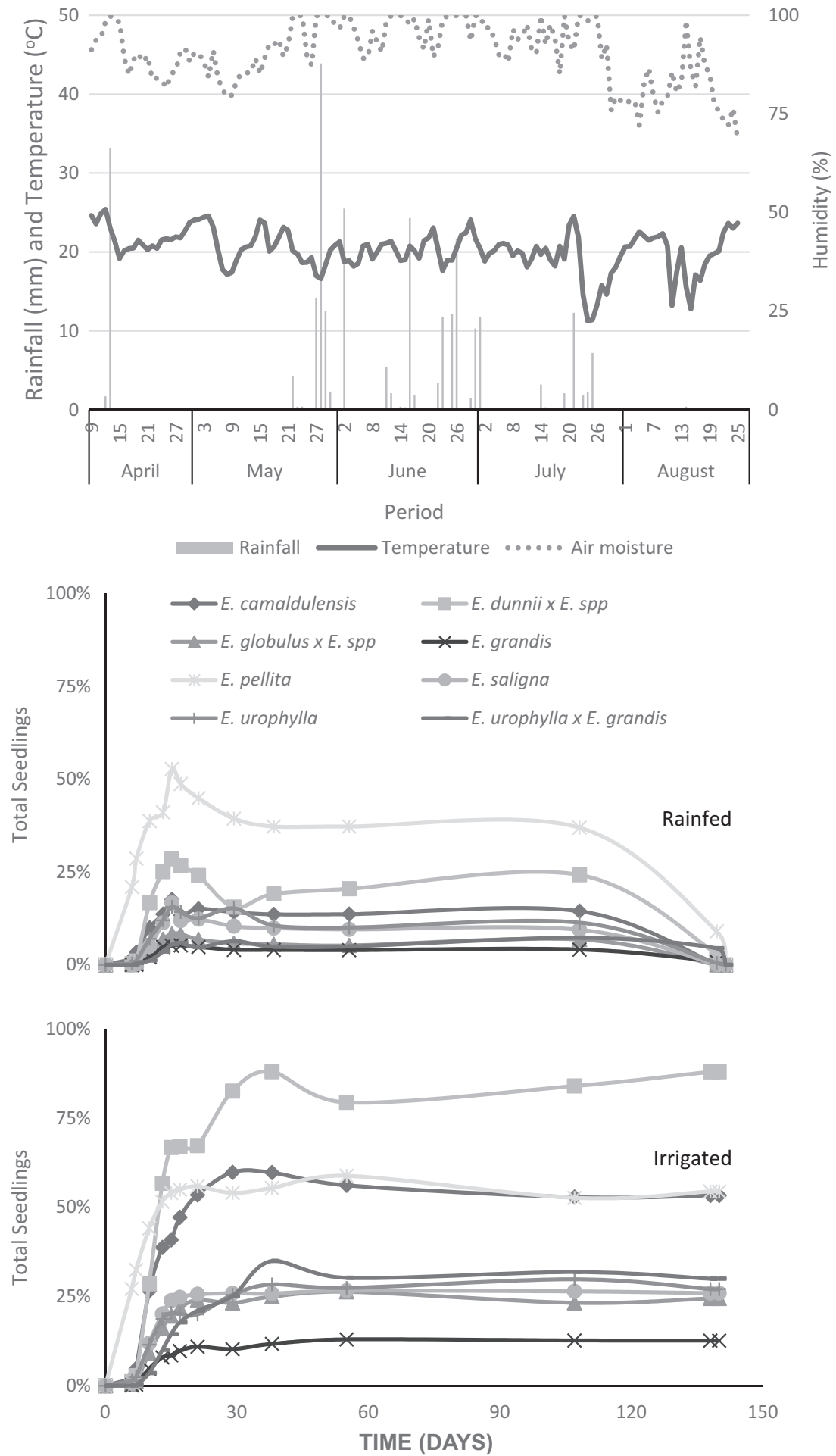

Fig. 2. Climatic conditions and number of total seedlings in rainfed and irrigated conditions - Experiment 2.

the soil was left bare only a few weeks after which the nonEucalyptus species could fill up the plots when favourable soil and/or air moisture occurred (e.g. at sites CBO and ANGA-2, with an average of 475 and 85 seedlings per plot, respectively). CBO is in the Atlantic Forest biome (tropical forest) where the use of eucalypts might facilitate regeneration of the natural vegetation in degraded areas (Silva et al., 1995; Feyera et al., 2002). Eucalypts are not invasive in this area and provide shade for native species regeneration. In our study, the very poor establishment of Eucalyptus might be also explained by the foraging of seedlings by leaf-cutting ants (Silva et al., 2011) which was not monitored. Atta sp. and Acromyrmex sp. cause extensive damage in commercial stands in South America (Ferreira Filho et al., 2015).

The importance of competition release of non-Eucalyptus species for Eucalyptus seedling establishment could be illustrated by eucalypts regeneration in areas disturbed by burning as observed for E. globulus in Australia (Larcombe et al., 2013). Fire is an important factor for Eucalyptus spp. regeneration by reducing competition of other plant species, similar to what we observed in bare soils. Fire disturbance could accelerate the naturalization 
of eucalypt around the commercial plantations in Brazil, as observed for example in Portugal with E. globulus (Águas et al., 2014). This issue is particularly important as Eucalyptus species usually present very-small seeds and fragile seedling in the very young stage. Fire also generates rapid availability of nutrients through the mineralization of organic matter and decreases the risk of insect predation. Eucalypts regeneration is strongly linked to fire events and seed dispersal following fire is considered as an evolutionary characteristic of some Eucalyptus species (O'Dowd and Gill, 1984; Spencer and Baxter, 2006). However, even after fire event, adequate conditions of precipitation and temperature are drivers of eucalypt wildlings establishment (Catry et al., 2015).

Even under favourable conditions (i.e., bare soil and high air moisture), the non-Eucalyptus species showed much higher regeneration ability than the Eucalyptus species did, which is consistent with previous observations in Brazil (Silva et al., 2011) and Australia (Skinner et al., 2010). Some natural regeneration of Eucalyptus seedlings were observed in old plantation areas in Australia (Larcombe et al., 2013) where numerous seed production cycles of eucalypts stand likely occurred. In these areas, the lack of intensive management, such as weeding, increases the possibility for seed dispersal and seedling establishment under favourable climatic conditions. By contrast, in Brazil commercial eucalypts plantations are usually managed in rotations of 6-8 years (Gonçalves et al., 2013) with regular weed control and transit of machines that drastically limits regeneration possibility, even if when eucalypts produce viable seeds after a few years after planting (Mora et al., 1981).

\section{Conclusions}

Eucalyptus species showed significant differences in seed germination and early seedling establishment under experimental conditions. Nevertheless, environmental conditions such as soil exposure/moisture and air humidity, overrides the differences between Eucalyptus species. Abundant seed germination of Eucalyptus was observed in controlled conditions. However, very poor Eucalyptus germination and seedlings survival was found in the field under experimental conditions. Eucalyptus species were much less adapted for wilding regeneration than the non-Eucalyptus species naturally found in the study areas. Our results suggest that the Eucalyptus species used for commercial plantations present poor ecological adaptation as invasive species in Brazil.

\section{Acknowledgments}

We would like to thank University of São Paulo State, Fibria and Futuragene for their collaborative efforts in the fieldwork and all the companies participating in the Cooperative Program of Pollen Dispersal (PRODIP) from the Research Institute and Forest Studies (IPEF) for their support. We also thank Trevor H. Booth, Marcio Araujo and two anonymous reviewers for their very helpful comments.

\section{Appendix A. Supplementary material}

Supplementary data associated with this article can be found, in the online version, at http://dx.doi.org/10.1016/j.foreco.2016.05. 007.

\section{References}

Águas, A., Ferreira, A., Maia, P., Fernandes, P.M., Roxo, L., Keizer, J., Silva, J.S., Rego, F. C., Moreira, F., 2014. Natural establishment of Eucalyptus globulus Labill in burnt stands in Portugal. For. Ecol. Manage. 323, 47-56.
Arnold, S., Kailichova, Y., Knauer, J., Ruthsatz, A.D., Baumgartl, T., 2014. Effects of soil water potential on germination of co-dominant Brigalow species: implications for rehabilitation of water-limited ecosystems in the Brigalow Belt bioregion. Ecol. Eng. 70, 35-42.

Boland, D.J., Brooker, M.I.H., Chippendale, G.M., Hall, N., Hyland, B.P.M., Johnston, R. D., Turner, J.D., 2006. Forest Trees of Australia. CSIRO publishing.

Booth, T.H., 2012. Eucalypts and their potential for invasiveness particularly in frost-prone regions. Int. J. Forest. Res. 7. http://dx.doi.org/10.1155/2012/837165 Article ID 837165.

Booth, T.H., 2014. 14 Modern tree colonisers from Australia into the rest of the world. Invas. Biol. Ecol. Theory: Insights From Contin. Transform., 304

Booth, T.H., 2015. Using a global botanic gardens database to help assess the capabilities of rare eucalypt species to cope with climate change. Int. Forest. Rev. 17, 259-268.

Booth, T.H., Broadhurst, L.M., Pinkard, E., Prober, S.M., Dillon, S.K., Bush, D., Young, A G., 2015. Native forests and climate change: lessons from eucalypts. For. Ecol. Manage. 347, 18-29.

Callaham, M.A.J., Stanturf, W.J., Hammond, W.J., 2013. Survey to evaluate escape of Eucalyptus spp. seedlings from plantations in Southeastern USA. Int. J. Forest. Res., 10 http://dx.doi.org/10.1155/2013/946374 Article ID 946374.

Catry, F., Moreira, F., Deus, E., Silva, J., Águas, A., 2015. Assessing the extent and the environmental drivers of Eucalyptus globulus wildling establishment in Portugal: results from a countrywide survey. Biol. Inv. 17, 3163-3181.

Cavalcante, A.D.M.B., Perez, S.C.J.G.A., 1995. Efeitos dos estresses hídrico e salino sobre a germinação de sementes de Leucaena leucocephala (Lam.) de Wit. Pesq. Agro. Brasil. 30, 281-289.

Daws, M.I., Crabtree, L.M., Dalling, J.W., Mullins, C.E., Burslem, D.F., 2008 Germination responses to water potential in neotropical pioneers suggest large-seeded species take more risks. An. Bot. 102 (6), 945-951.

Erfmeier, A., Bruelheide, H., 2010. Invasibility or invasiveness? Effects of habitat, genotype, and their interaction on invasive Rhododendron ponticum populations. Biol. Inv. 12, 657-676.

Ferreira Filho, P.J., Wilcken, C.F., Neves, D.A., Pogetto, M.H., Carmo, J.B., Guerreiro, J. C., Zanuncio, J.C., 2015. Does diatomaceous earth control leaf-cutter ants (Hymenoptera: Formicidae) in the Eucalyptus plantations? J. Econ. Entomol., 066

Feyera, S., Erwin, B., Ulrich, L., 2002. Exotic trees as nurse-trees for the regeneration of natural tropical forests. Trees 16, 245-249.

Flory, S.L., Lorentz, K.A., Gordon, D.R., Sollenberger, L.E., 2012. Experimenta approaches for evaluating the invasion risk of biofuel crops. Environ. Res. Lett. 7, 045904

Forsyth, G.G., Richardson, D.M., Brown, P.J., Van Wilgen, B.W., 2004. A rapid assessment of the invasive status of Eucalyptus species in two South African provinces: working for water. South Afric. J. Sci. 100, 75.

Godfree, R., Lepschi, B., Mallinson, D., 2004. Ecological filtering of exotic plants in an Australian sub-alpine environment. J. Veg. Sci. 15, 227-236.

Gonçalves, J.L.M., Alvares, C.A., Higa, A.R., Silva, L.D., Alfenas, A.C., Stahl, J., Ferraz, S. F.B., Lima, W.P., Brancalion, P.H.S., Hubner, A., Bouillet, J.P.D., Laclau, J.P. Nouvellon, Y., Epron, D., 2013. Integrating genetic and silvicultural strategies to minimize abiotic and biotic constraints in Brazilian eucalypt plantations. For. Ecol. Manage. 301, 6-21.

Gordon, D.H., Flory, L.S., Cooper, A.L., Morris, S.K., 2012. Assessing the invasion risk of Eucalyptus in the United States Using the Australian Weed Risk Assessment. Int. J. For Res., 7 Article ID 203768

Gurevitch, J., Padilla, D.K., 2004. Are invasive species a major cause of extinctions? Trends Ecol. Evol. 19, 470-474.

Harwood, C., 2011. New introductions - doing it right in developing a eucalypt resource. In: Walker, J. (Ed.), Learning From Australia and Elsewhere. Wood Technology Research Centre, pp. 125-136.

Higgins, S.I., Richardson, D.M., 2014. Invasive plants have broader physiological niches. Proc. Natl. Acad. Sci. USA 111, 10610-10614.

Kozlowski, T.T., 2002. Physiological ecology of natural regeneration of harvested and disturbed forest stands: implications for forest management. For. Ecol Manage. 158, 195-221.

Larcombe, M.J., Silva, J.S., Vaillancourt, R.E., Potts, B.M., 2013. Assessing the invasive potential of Eucalyptus globulus in Australia: quantification of wildling establishment from plantations. Biol. Invas. 15 (12), 2763-2781.

Lorentz, K.A., Minogue, P.J., 2015. Potential invasiveness for Eucalyptus species in Florida. Invas. Plant Sci. Manage. 8, 90-97.

Mattei, V.L., Longhi, S.J., 2001. Avaliação da regeneração natural de Eucalyptus paniculata Smith. Cienc. Florest. 11, 55-65.

Mora, A.L., Pinto Junior, J.E., Fonseca, S.D., Kageyama, P.Y., 1981. Aspectos da produção de sementes de espécies florestais. Ser. Tec. IPEF 2, 60.

Mc Carragher, S., Goldblum, D., Rigg, L., 2011. Geographic variation of germination, growth, and mortality in sugar maple (Acer saccharum): common garden and reciprocal dispersal experiments. Phys. Geogr. 32, 1-21.

O'Dowd, D.J., Gill, A.M., 1984. Predator satiation and site alteration following fire: mass reproduction of alpine ash (Eucalyptus delegatensis) in southeastern Australia. Ecology, 1052-1066.

Perkins, L.B., Leger, E.A., Nowak, R.S., 2011. Invasion triangle: an organizational framework for species invasion. Ecol. Evol. 1, 610-625.

Ritter, M., Yost, J., 2009. Diversity, reproduction, and potential for invasiveness of Eucalyptus in California. Madroño 56, 155-167.

Richardson, D.M., Rejmánek, M., 2011. Trees and shrubs as invasive alien species - a global review. Div. Distr. 17, 788-809. 
Ruthrof, K.X., 2004. Invasion by Eucalyptus megacornuta of an urban bushland in Southwestern Australia. Weed Technol. 18, 1376-1380.

Sentelhas, P.C., Dalla Marta, A., Orlandini, S., Santos, E.A., Gillespie, T.J., Gleason, M.L 2008. Suitability of relative humidity as an estimator of leaf wetness duration. Agric. Forest. Meteor. 148, 392-400.

Silva, M.C., Scarano, F.R., Cardel, F.S., 1995. Regeneration of an Atlantic forest formation in the understorey of a Eucalyptus grandis plantation in south-eastern Brazil. J. Trop. Ecol. 11, 147-152.

Silva, P.H.M., Poggiani, F., Sebbenn, A.M., Mori, E.S., 2011. Can Eucalyptus invade native forest fragments close to commercial stands? For. Ecol. Manage. 261, 2075-2080.

Silva, P.H.M., Poggiani, F., Lima, W.D.P., Libardi, P.L., 2014. Soil water dynamics and litter production in eucalypt and native vegetation in southeastern Brazil. Sci. Agric. 71, 374-379.

Skinner, A.K., Lunt, I.D., Mcintyre, S., Spooner, P.G., Lavorel, S., 2010. Eucalyptus recruitment in degraded woodlands: no benefit from elevated soil fertility. Plant Ecol. 208, 359-370.
Spencer, R.J., Baxter, G.S., 2006. Effects of fire on the structure and composition of open eucalypt forests. Austral. Ecol. 31 (5), 638-646.

Stanton-Geddes, J., Tiffin, P., Shaw, R.G., 2012. Role of climate and competitors in limiting fitness across range edges of an annual plant. Ecology 93, 1604-1613.

Tererai, F. Gaertner, M. Jacobs, S.M., Richardson, D.M., 2013. Eucalyptus invasions in riparian forests: effects on native vegetation community diversity, stand structure and composition. For. Ecol. Manage. 297, 84-93.

Villela, F.A., Doni Filho, L., Sequeira, E.L., 1991. Tabela de potencial osmótico em função da concentração de polietileno glicol 6.000 e da temperatura. Pesq. Agrop. Bras. 2, 1957-1968.

Williams, M.C., Wardle, G.M., 2007. Pinus radiata invasion in Australia: identifying key knowledge gaps and research directions. Austral. Ecol. 32, 721-739. 